\title{
Case study: The impact of organizing the George Enescu International Festival on the branding and promotion of Bucharest city
}

\author{
Florin-Alexandru ALEXE, Ana-Claudia ŢAPARDEL \\ Bucharest Academy of Economic Studies No. 6, Piața Romană, Bucharest, 010374, Romania
}

Email address:

alexeflorin2000@yahoo.com (Florin-Alexandru ALEXE), tanaclaudia@yahoo.com (Ana-Claudia ȚAPARDEL)

To cite this article:

Florin-Alexandru ALEXE, Ana-Claudia ȚAPARDEL. Case Study: The Impact of Organizing the George Enescu International Festival on the Branding and Promotion of Bucharest City. International Journal of Economics, Finance and Management Sciences. Vol. 1, No. 5, 2013, pp. 241-246. doi: 10.11648/j.ijefm.20130105.15

\begin{abstract}
The George Enescu International Festival and Competition - appreciated all across Europe - will be in 2013 at its $21^{\text {st }}$ edition. The Festival has been inaugurated on September $4^{\text {th }} 1958$, but it was only in the last decade that it has really become an impressive display of culture: in 2009, there were 175 events, in which no less than 1800 foreign artists and 1300 local artists took part. The participants included 13 symphonic orchestras from Europe, 14 from other continents, 19 smaller groups, 6 choirs, 47 soloists. Organising such an event has been a massive challenge for the local administration of Bucharest. The present paper traces the impact of organising the Enescu Festival, the largest event in Romanian cultural life, and the echoes it has on the branding of Bucharest, taking into account its visual concept, the infrastructure used and its impact on classic and new media.
\end{abstract}

Keywords: Branding Strategy, City Branding, City Promotion

\section{Introduction and Literature Review}

Tourism may be said to begin as early as the $1^{\text {st }}$ century $\mathrm{BC}$, when young middle- and upper-class Romans took the habit of travelling to the most beautiful Greek cities to further their education and marvel at the sights (Gyr, 2012). Then and now, when tourism has become a mass phenomenon, it is the public image of a place that turns it into a destination, and the local culture, history and patrimony are essential components of what the Romans called fama, 'fame', and what we now call the 'brand' of a place.

The current economic context has decreased the appetite for tourism ${ }^{1}$ and, under this circumstances, efforts by cities to stand out are all the more relevant. In attracting travellers, there is a clear advantage for those cities which have succeeded in developing a strong brand (Moilanen \& Rainisto, 2009, p.3).

\footnotetext{
${ }^{1}$ According to data provided by Eurostat, the average duration of both business trips and holiday trips has decreased substantially since 2005: $\mathrm{http}$ ://epp.eurostat.ec.europa.eu/statistics_explained/index.php/Tourism statistics, (see in particular Figure 2 on that page).
}

In the region, Bucharest competes mainly with Budapest and Sofia, the capitals of neighbouring countries. On the top 15 global news portals, Budapest has superior exposure: Bucharest has $37 \%$ less mentions overall. However, tourism-related queries on search engines are significantly lower (by as much as $92 \%$ ) than for Budapest. This indicates that significant effort must be invested by Romanian stakeholders to consolidate their local brands.

The benefits of a strong brand go well beyond the sphere of tourism: it contributes to the construction of local identity (Deffner \& Metaxas, 2010, p.54), and this, in turn, reverberates widely, contributing alongside other factors to a general increase in the standards of living. In particular, it is a catalyst for the development of creative industries (Pratt, 1997).

Across Europe, policymakers increasingly appeal to culture as a whole and to the creative industries in particular to stimulate competitiveness in the context of globalisation. It is recognised that culture engenders benefits in numerous areas. Not only does it act as a bridge inside heterogeneous communities (studies have shown that exposure to culture reduces ethnocentrism and is a greater coagulating factor in 
communities even than sports ${ }^{2}$ ), but it also generates jobs and net wealth: $2.6 \%$ of European GDP (Unlocking the Potential of Cultural and Creative Industries, p. 2), almost 6 million employed, i.e. $3.1 \%$ of the active population (ESSnet 2012 Final Report, p. 170).

City branding, as an instrument applied equally to the economic sectors of creative industries and tourism, will act as a bridge between the two, multiplying benefits. In this context, the fact that Bucharest organises one of the largest festivals of classical music in Europe may be considered significant. While the main impact of the festival is undoubtedly in the world of arts, offering a venue for top performers and the public to enjoy the works of great composers, the present paper focuses on another aspect of the event, namely its impact on city branding and promotion.

\section{Paper's Specific Objectives and Methodology}

The following pages contain an analysis of the visual and promotional concept of the George Enescu International Festival, of the infrastructure made available to it and of its media coverage. The aim is to gauge its impact in public perception, both in Romania and abroad through classic mass-media and through the new media.

The impact will be analysed both quantitatively and qualitatively, resulting in a research of:

$>$ how online consumers behave;

$>$ how visible Bucharest was during the time frame of the investigation,

$>$ to what extent the presence of Bucharest in international media was connected to the George Enescu International Festival.

This is essential, for in the absence of a commensurate impact, even large scale events remain useless for the purpose of city branding. It will be demonstrated that there was a marked improvement in the image of Bucharest, at a time marked by the economic crisis and fierce competition between city brands across the globe.

\section{George Enescu Festival in Context}

The George Enescu Festival is a large scale musical event, named after the most famous Romanian composer. George Enescu was born in 1881 and has shown musical abilities at a very early age (Gavoty, 2005; Cophignon, 2006). He started creating original pieces of music by the time he was 6 . He studied in Vienna and Paris (1888 to 1894 and 1895 to 1899 , respectively). While in Paris, he created his first major pieces, but it was only at the turn of the $20^{\text {th }}$ century that he started producing his best works: the two Romanian Rhapsodies, the Symphony No. 1 in E-flat major, the Orchestral Suite No. 1 in C major, etc. In 1931, he finished

\footnotetext{
${ }^{2}$ Keuchel \& Wiesand, 2006, p. 161.
}

his most famous creation, the opera Oedipe. A great violinist and an excellent pedagogue, he taught in Romania and abroad. Among his students, one may name Yehudi Menuhin, Ivry Gitlis, Christian Ferras, Arthur Grumiaux, and Ida Haendel. After World War II, he left Romania to avoid living under the Communist regime and settled in Paris, where he died in 1955.

Three years after his death, in 1958, the first Festival dedicated to his memory was organised in Bucharest. Initially, it was held every three years, but since 2001, it has been organised every two years, featuring an increasing number of musical events and drawing in numerous artists of the highest level.

In the 2011 edition, there were over 160 performances by Wiener Philharmoniker, Israel Philharmonic Orchestra, Staatskapelle Berlin, Orchestra dell'Accademia Nazionale di "Santa Cecilia" di Roma, Orchestre National de France, London Symphony Orchestra, Mariinsky Orchestra, Liverpool Philharmonic Orchestra, Residentie Orkestr, Hungarian National Philharmonic, Gulbenkian Symphony Orchestra, as well as numerous soloists.

The 2013 edition $\left(1^{\text {st }}-28^{\text {th }}\right.$ of September) will include over 150 performances by Concertgebouw Amsterdam, Royal Philharmonic London, Staatskapelle Berlin, Rundfunk Sinfonieorchester (Berlin), Münchener Philharmoniker, Royal Stockholm Philharmonic, National Philharmonic Of Russia, Pittsburgh Symphony Orchestra, Harmonius Chamber Orchestra (Osaka), Camerata Salzburg, and others. $^{3}$

As in the previous edition, organisers have planned musical events in several cities of Romania (Arad, Bacău, Braşov, Cluj, Iași, Oradea, Sibiu and Timișoara), but the bulk of the performances will remain in Bucharest. In the 2011 edition of the Festival, out of the 160 performances, only 23 have been organised outside the capital of Romania. Thus, while the Festival does have a national footprint, it remains firmly associated with the city of Bucharest, and the analysis of this event as a focal point in city branding remains valid.

This prevalence of Bucharest does not come as a result of active participation by the local authorities in organising the event: the 2013 edition is in fact the first for which the City Council will provide any direct funding. ${ }^{4}$ However, historical reasons make Bucharest the ideal candidate among Romanian cities for hosting this major event. It has had a long history as capital city. Not surprisingly, therefore, it has become the centre of the political, administrative, economic and cultural life of Romania. In time, the combination of these factors has made it so that Bucharest is one of the few cities in Romania whose infrastructure is robust enough to

\footnotetext{
3 The list of participants has been retrieved from the Festival's official page, at http://festivalenescu.ro/festival-2013/editia-xxi. Retrieved on June $28^{\text {th }}$ 2013.

4 The press release announcing the partnership may be viewed here: http://festivalenescu.ro/news/comunicat-de-presa-guvernul-romaniei. Retrieved on June $28^{\text {th }} 2013$.
} 
cope with an event of such a scale, bringing together over 2000 local and international performers and spectators estimated in the region of 125000 . One example is eloquent: while the number of tourists visiting Bucharest has almost doubled from 2001 to 2008 (soaring from 480,000 to 950,000), the lodging capacity of Bucharest has kept up the pace, for in 2008 hotels had an occupancy rate of only $34.9 \%$ (Anuarul Municipiului Bucuresti, 2009, p. 154).

Also, Bucharest has the advantage of a vivid market for cultural products. The George Enescu Festival is by no means a singular occurrence in the cultural landscape of the city. Listed below are a number of other musical events, which have demonstrated an ability to become firmly established, by succeeding in reaching at least their fifth edition:

- Singing Competition 'Masters of Lyrical Art' (5 $5^{\text {th }}$ edition $)^{5}$

- EUROPAfest $\left(20^{\text {th }} \text { edition }\right)^{6}$

- Bucharest International Jazz Competition $\left(7^{\text {th }} \text { edition }\right)^{7}$

- B’ESTFEST $\left(5^{\text {th }} \text { edition }\right)^{8}$

- Summer Music Festival "Little Paris" $\left(6^{\text {th }} \text { edition }\right)^{9}$

- Festivalul internațional al artelor spectacolului muzical "Viața e frumoasă" ( $6^{\text {th }}$ edition $)^{10}$

These events are private initiatives, in the sense that they do not stem from a branding strategy generated by the City Council. They often collaborate little with each other and there is little effort to generate city-wide events. A notable exception has been the George Enescu Festival, which has managed to generate in 2011 a partner event, the Bucharest e-Biennale, an event dedicated to visual arts, organised in cooperation with the National Museum of Art, the Museum of the Romanian Peasant, Ann Art and the University of Fine Arts from Bucharest. Beyond the sheer scale of the Festival, this capacity to stimulate creative synergies makes it the ideal candidate for a flagship event, a pillar for the branding of Bucharest.

It is perhaps paradoxical that, while the organisers recognise this character and invest in media coverage, the local administration has yet to devise a coherent strategy for city branding. In this respect, the situation seems closer to the North American practice, in which branding efforts are primarily private, than to European, centralist tradition (Alexe, 2011).

\footnotetext{
5 Official site:

http://onb.operanb.ro/en/component/content/article/88-stiri/stiri-homepage $/ 371$-concurs-interna $\%$ C $8 \% 9$ Bional-de-canto- 2013 . Retrieved on June $28^{\text {th }}$ 2013.

${ }^{6}$ Official site: http://www.jmevents.ro/evenimente/europafest. Retrieved on June $28^{\text {th }} 2013$.

${ }^{7}$ Official site: http://www.jazzcompetition.ro/. Retrieved on June $28^{\text {th }}$ 2013.

${ }^{8}$ Official site: http://bestfest.ro/editia2013/?lang=en. Retrieved on June $28^{\text {th }} 2013$.

9 Official site: http://www.bucharestfestival.com/index.html. Retrieved on June $28^{\text {th }} 2013$.

${ }^{10}$ Official site: http://www.opereta.ro/festival2012/. Retrieved on June $28^{\text {th }}$ 2013.
}

\section{Media Coverage Report for the Enescu Festival}

\subsection{General Assessments of Previous Editions}

Assessment of previous editions in the international press has been overtly positive. A typical example is the article 'How music can restore a nation's pride', published in The Telegraph by Ivan Hewett in 2009. In it, the author qualified the George Enescu Festival as 'one of the world's great music festivals' and confessed to being astonished by 'the scale and lavishness of what's in store'.

\subsection{Media Coverage of the Latest Edition (August-September 2011)}

The figures below have been obtained from a number of reports made available upon the authors' request by the Romanian Ministry of Culture: Media coverage analysis for the George Enescu International Festival, Media report for the George Enescu International Festival and Summary of the George Enescu International Festival and Competition, 21 st edition, September $1^{\text {st }}-28^{\text {th }} 2013$.

During the period indicated, a number of 1164 articles were published, covering the Festival. The bulk of these appeared in online (693) and in printed publications (400), nearly ten times the coverage received from TV and radio stations.

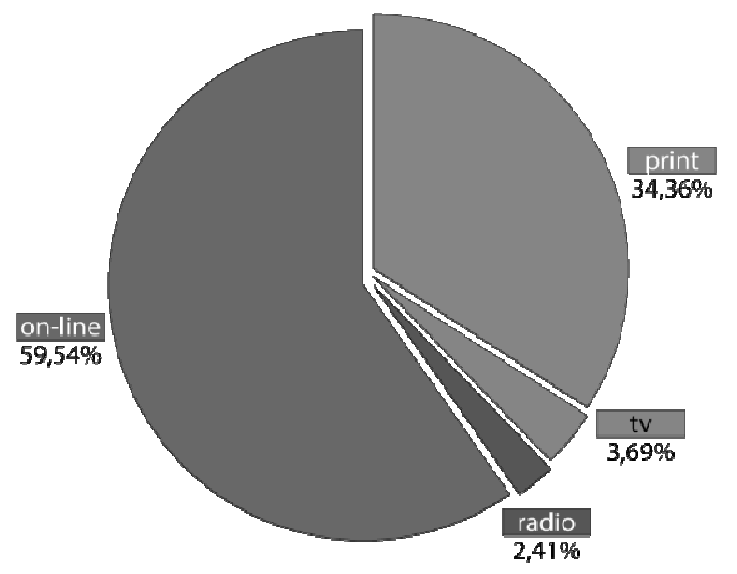

Source: Media coverage analysis for the George Enescu International Festival, p. 6.

Figure 1. Published articles

The high point of the media coverage has been touched on the first day, with 47 articles, of which 40 in printed press. News coverage of the Festival has reached $68.1 \%$ of the adult urban population of Romania, totalling 4068000 readers. In print, the highest advertising value equivalent (AVE) has been reached by articles in Jurnalul Naţional, namely $74872 €$. On TV and radio, the highest AVE has been $384350 €$ for the national television channel, TVR1 and 14 371 for the main radio channel of the national broadcasting company, Radio România Actualități. 
A total of 173 Romanian and international sites have provided news coverage of the Festival, publishing 693 articles.

The Romanian sites which covered the Festival most extensively were as follows: www.pescurt.ro (51), www.niuzer.ro (48), www.adevarul.ro (44), www.amosnews.ro (30), www.jurnalul.ro (26), www.zf.ro (24), www.newspad.ro (18), www.sapteseri.ro (17) www.romanialibera.ro (17), www.ziare.com (15), www.evz.ro (13), www.observatorcultural.ro (12), www.prwave.ro (10). Most of them are online outlets of national newspapers, but some are exclusively online news providers.

Of the 21 international sites, most belonged to prestigious news providers: www.dwworld.de (Germany), www.independent.co.uk (United Kingdom), www.telegraph.co.uk (United Kingdom), www.la-croix.com (France), www.lepoint.fr (France), www.lesechos.fr (France), www.lexpress.fr (France). Most articles (9) appeared in France: 4 on www.la-croix.com, 2 on www.lesechos.fr and one on www.lexpress.fr, www.lepoint.fr, and www.vousnousils.fr.

By comparison, only 71 news items appeared on TV and radio channels, although it is true that the monitoring only included news broadcasts, and not other shows. In terms of audience, the largest rating was in the historical region of Muntenia/Oltenia (72.9\%).

\subsection{Attributes}

Of the attributes associated with the Festival, a solid majority were positive. $28 \%$ of them connected the event with the idea of promoting Romania's image: 'appreciated by European press', 'an attraction for foreign tourists', 'international prestige', 'cultural brand for Romania', 'a large-scale event in Europe', 'a cultural symbol of Romania', 'deemed by the international press as a direct competitor to the Salzburg Festival', 'the most important musical event in Eastern Europe'.

On the other hand, 'bad acoustics in the Palace Hall' has also been picked up by the press and it appears in $7 \%$ of the key messages associated with the Festival.

The most important attributes of the Festival, arranged by impact (net audience and number of readers) can be seen in the table below:

Table 1. The Festival Attributes

\begin{tabular}{|c|c|c|c|}
\hline Attribute & Net audience & Readers (thousands) & Articles \\
\hline Appreciated in the European press & 19.2 & 1144 & 6 \\
\hline Varied programme & 19.1 & 1141 & 10 \\
\hline Prestigious guests & 15 & 898 & 17 \\
\hline Bad acoustics in the Palace Hall & 12.2 & 731 & 9 \\
\hline Good organisation & 10.8 & 645 & 7 \\
\hline Attraction for foreign tourists & 10 & 600 & 2 \\
\hline International prestige & 8.6 & 514 & 15 \\
\hline Cultural brand for Romania & 8.5 & 507 & 11 \\
\hline Well promoted & 7.5 & 446 & 4 \\
\hline Memorable event & 7 & 421 & 3 \\
\hline Major musical event in Europe & 6.9 & 415 & 3 \\
\hline Cultural symbol of Romania & 6.9 & 415 & 4 \\
\hline Excellence & 6.9 & 415 & 2 \\
\hline Fabulous concerts & 6.9 & 415 & 3 \\
\hline Prestige & 6.9 & 415 & 3 \\
\hline Musical feast & 6.9 & 415 & 3 \\
\hline Premier shows & 3.7 & 222 & 2 \\
\hline Deemed by the international press a rival to the Salzburg Festival & 2.5 & 148 & 1 \\
\hline The most complex cultural event in Romania & 2.4 & 143 & 3 \\
\hline Large-scale event & 1.9 & 111 & 3 \\
\hline Spiritual joy & 1.9 & 111 & 2 \\
\hline Greatest classical music event in Romania & 1.8 & 108 & 2 \\
\hline Distinction & 0.6 & 36 & 2 \\
\hline
\end{tabular}




\begin{tabular}{|c|c|c|c|}
\hline Attribute & Net audience & Readers (thousands) & Articles \\
\hline One of the best editions & - & - & 1 \\
\hline Success with the public & - & - & 1 \\
\hline Support from private enterprises & - & - & 1 \\
\hline Success & - & - & 2 \\
\hline The most important musical event in Eastern Europe & - & - & 1 \\
\hline Logistical effort & - & - & 6 \\
\hline Exceptional event & - & - & 6 \\
\hline High quality festival & - & - & 2 \\
\hline One of the best things Romania has to offer & - & - & 1 \\
\hline
\end{tabular}

Source: Media coverage analysis for the George Enescu International Festival, p. 14.

\subsection{Interest in the Festival, as Seen through the Queries on Search Engines}

Our analysis continues with a number of graphs indicating public interest in the event, as seen through the queries in internet search engines. The tool used to compile these results was Google Trends.

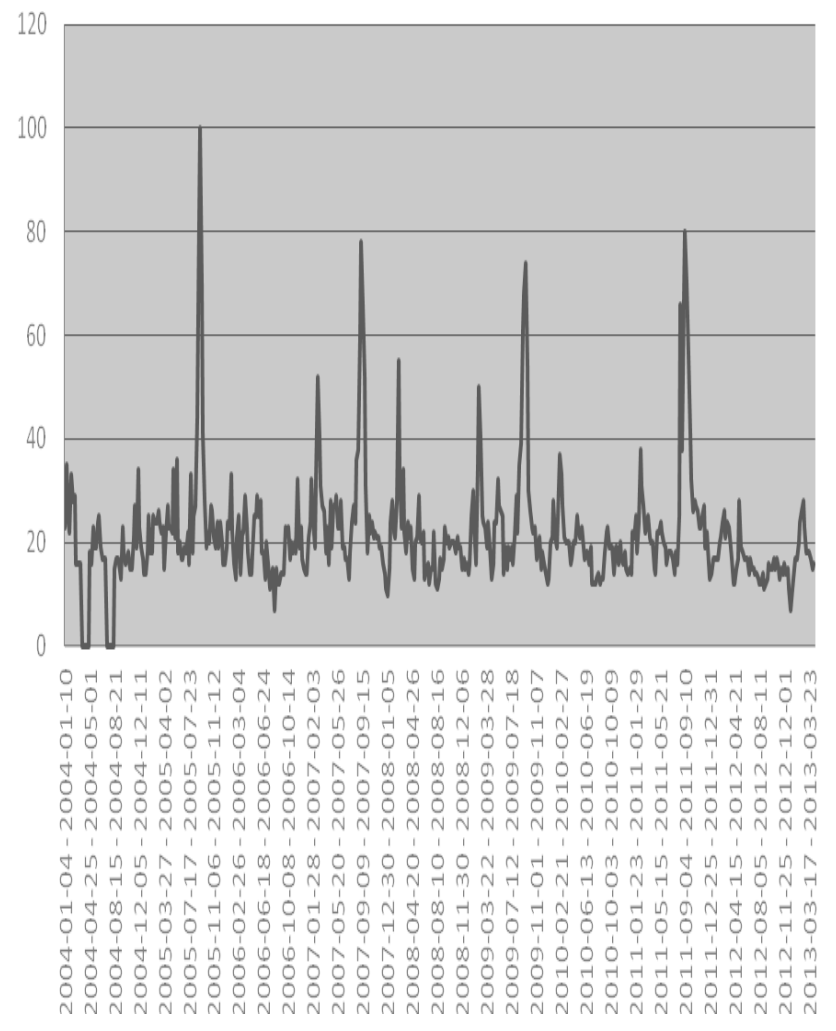

Source: Google Trends Analysis, 2013

Figure 2. Web searches for Enescu related keywords 2004 - 2013

Major spikes are visible in 2005, 2007, 2009 and 2011. These are the years when the festival was held in Bucharest. It is clear, therefore, that the Festival is a major element in promoting worldwide the name of the great Romanian composer.

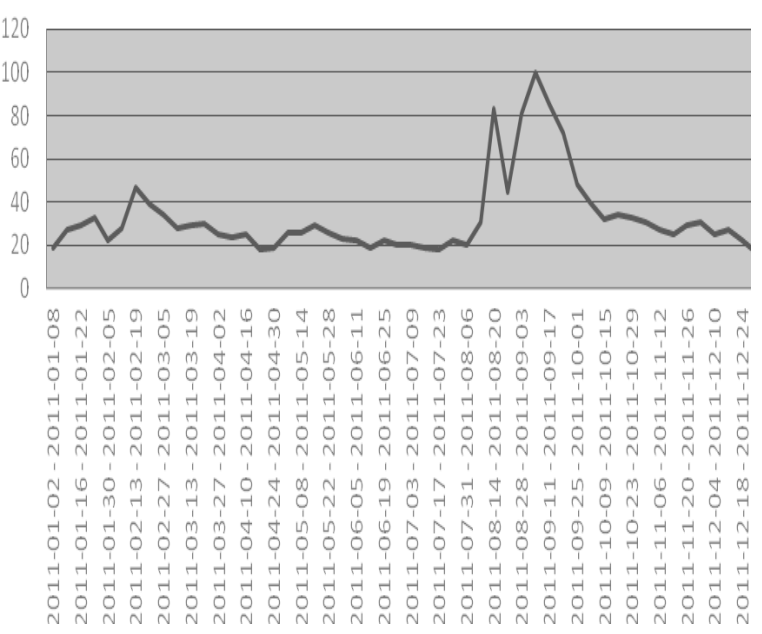

Source: Google Trends Analysis, 2013

Figure 3. Web searches for Enescu related keywords 2011

During the time of the festival the major web search interest came from Bucharest, in Romania. Out of 13 top keywords, 11 were directly linked to the festival.

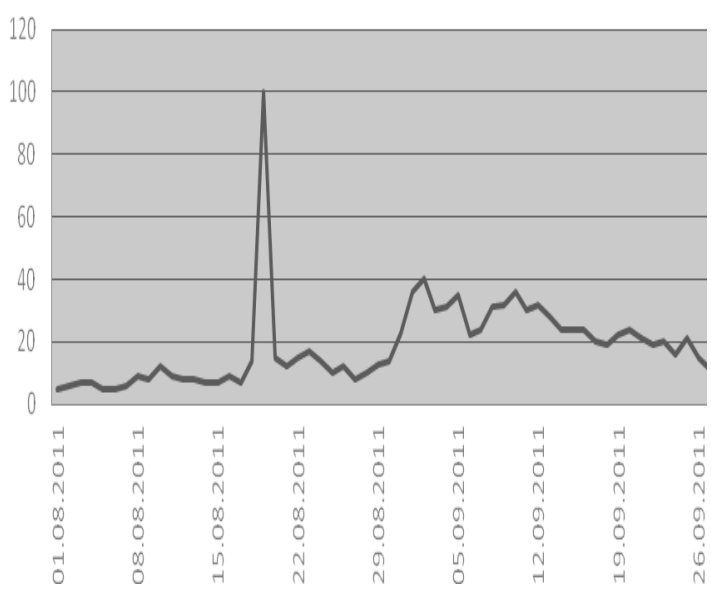

Source: Google Trends Analysis, 2013

Figure 4. Web searches for Aug-Sep 2011 


\subsection{Preparing the 2013 Edition}

The internal and external media drive to promote the George Enescu Festival and confirm the country brand will be coordinated by the co-producers of the Festival (The Romanian Radio Society, The Romanian Television Society, the Romanian Cultural Institute and the Bucharest City Council), alongside representatives of major news broadcasting stations (Antena 3, Realitatea TV), press companies (Adevărul Holding, România Liberă), as well as foreign media partners (CNN, Euronews, Eurosport, Mezzo, Rfi, Deutsche Welle) and PR representatives of the Festival in Belgium, France, Germany, Italy and the United Kingdom.

As part of this drive, a video ad has been produced by the creative team of the Festival, Ioana Gheorghiu and Robert Blaj. The musical background is provided by Enescu's Sonata no. 3 for Violin and Piano in A minor. The ad has been broadcast on CNN until February $3^{\text {rd }}$ and it has enjoyed great visibility, as it appeared even during the festivities related to Barack Obama's investment as President of the United States for a second term.

For domestic audience, the ad will run on Romanian channels in the period running up to the Festival, September $1^{\text {st }}-28^{\text {th }}$. It may be viewed on-line at the following address: http://www.youtube.com/watch?v=pzzxUKvJdPk.

\section{Conclusions}

The present paper is an urge to public administrators and private stakeholders to invest in large-scale cultural events. Following the analysis of the George Enescu International Festival as a case study, it has become clear that organising such a large-scale cultural event has beneficial effects on the branding of a city. This is due to its media and online exposure generated by the famous musical events and by the presence of high level artists, which can attract a lot of domestic and international tourists.

It is of the utmost importance to continue and build upon the tradition of organising impactful cultural events as a major component of the cities' branding and promotion strategy, and also for the Bucharest image and brand.

\section{Acknowledgements}

This work was co-financed from the European Social Fund through Sectoral Operational Programme Human Resources Development 2007-2013; project number POSDRU/107/1.5/S/77213, Ph.D. for a career in interdisciplinary economic research at the European standards".

\section{References}

[1] Alexe, F. (2011). Case Study: Bucharest City Brand. Between the American and the European models. Râmnicu Vâlcea: Raport în cadrul Conferin $\square$ ei Doctorale - „Provocări actuale în $\square$ tiin $\square$ a economică”.

[2] Cophignon, A. (2006). Georges Enesco. Paris: Fayard.

[3] Deffner, A., \& Metaxas, T. (2010). Place marketing, local identity and branding cultural images in Southern Europe: Nea Ionia, Greece and Pafos, Cyprus. In Ashworth, G.J. \&

[4] Gavoty, B. (2005). Amintirile lui George Enescu. Bucuresti: Curtea Veche Publishing.

[5] Kavaratzis, M. (eds), Towards Effective Place Brand Management (pg. 49-69). Northampton: Edward Elgar Publishing.

[6] Keuchel, S. \& Wiesand, A.J. (eds.) (2006). Das 1. Jugend-KulturBarometer: Zwischen Eminem und Picasso, Bonn: Arcult Media.

[7] Moilanen, T., \& Rainisto, S. (2009). How to Brand, Nations, Cities and Destinations - A Planning Book for Place Branding. New York: Palgrave Macmillan.

[8] Pratt, A. (1997). The cultural industries production system: a case study of employment change in Britain 1984-91. Environment and Planning, 29 (11), 53-74.

[9] Gyr, U. (December, 2010). The History of Tourism: Structures on the Path to Modernity, European History Online, from http://www.ieg-ego.eu/gyru-2010-en, retrieved on 28 th of June 2013.

[10] Hewett, I. (2009). How music can restore a nation's pride. The Telegraph, September $3^{\text {rd }} 2009$. Retrieved at:

[11] http://www.telegraph.co.uk/culture/music/classicalmusic/61 30306/How-music-can-restore-a-nations-pride.html, retrieved on 28th of June 2013.

[12] Directia Regionala de Statistica a Municipiului Bucuresti, Anuarul Municipiului Bucuresti, 2009, from http://www.bucuresti.insse.ro/cmsbuc/rw/pages/index.ro.do, retrieved on 28th of June 2013.

[13] European Statistical System Network on Culture, 2012 Final report, http://ec.europa.eu/culture/our-policy-development/docume nts/ess-net-report-oct2012.pdf, retrieved on 28th of June 2013.

[14] European Commission. Green Paper. Unlocking the potential of cultural and creative industries (2010). from

http://eur-lex.europa.eu/LexUriServ/LexUriServ.do?uri=CO M:2010:0183:FIN:EN:PDF, retrieved on 28th of June 2013.

[15] European Commission. Tourism Statistics, from http://epp.eurostat.ec.europa.eu/statistics_explained/index.p hp/Tourism statistics, retrieved on 28th of June 2013. 